\title{
Emergency funding public policy for disaster response in Brazil from 2013 to 2017
} Política pública de auxílio financeiro para resposta a
desastres no Brasil no período 2013-2017

Victor Marchezini ${ }^{\mathrm{a}}$

Adriano Mota Ferreirab

Glauston Roberto Teixeira de Limac

Demerval Aparecido Gonçalves ${ }^{d}$

${ }^{a} P h D$ in Sociology, researcher at Cemaden, São José dos Campos, SP, Brazil

E-mail: victor.marchezini@cemaden.gov.br

${ }^{b}$ PhD student of the Disaster Postgraduate Program, Institute of Science and Technology, São Paulo State University, São José dos Campos, SP, Brazil E-mail: adriano.mota@unesp.br

${ }^{c} \mathrm{PhD}$ in Electronic and Computer Engineering, researcher at Cemaden, São José dos Campos, SP, Brazil E-mail: glauston.lima@cemaden.gov.br

${ }^{d}$ Master in Aeronautical Infrastructure Engineering, researcher at Cemaden, São José dos Campos, SP, Brazil E-mail: demerval.goncalves@cemaden.gov.br

doi:10.18472/SustDeb.v11n2.2020.31268

\begin{abstract}
Public financial aid policies for disaster response actions are a poorly studied topic. This article analyzed information extracted from the databases of the State of Emergency and State of Public Calamity decrees and the costs of disaster relief and response in Brazil, in the period 2013-2017, based on its spatial-temporal distributions. Disaster relief and response costs are also used in a cross-analysis with municipal indicators such as the Human Development Index (HDI) and the per capita Gross Domestic Product (GDP). It was identified that spending exceeded R\$ 800 million. State civil defences accounted for most of the resources used (76.4\%). In a universe of 564 municipalities that used financial assistance via the Civil Defense Payment Card, a concentration of $40 \%$ of resources was found in 30 municipal civil defences, some of which in municipalities with high HDI and GDP per capita.
\end{abstract}

Keywords: Disasters. Civil defense. Public spending. Development.

\section{RESUMO}

As políticas públicas de auxílio financeiro para ações de resposta a desastres são um tema pouco estudado. Neste artigo analisaram-se informações extraídas das bases de dados dos decretos de 
Situação de Emergência e Estado de Calamidade Pública e dos custos de socorro e resposta a desastres no Brasil, no período 2013-2017, a partir de suas distribuições espaço-temporal. Os custos de socorro e resposta a desastres são também utilizados em uma análise cruzada com indicadores municipais, como o Índice de Desenvolvimento Humano (IDHM) e o Produto Interno Bruto (PIB) per capita. Identificou-se que os gastos excederam $R \$ 800$ milhões. As defesas civis estaduais responderam pela maior parte dos recursos utilizados (76,4\%). Em um universo de 564 municípios que utilizaram o auxílio financeiro via Cartão de Pagamento de Defesa Civil, constatou-se a concentração de $40 \%$ dos recursos em 30 defesas civis municipais, algumas das quais em municípios com alto IDHM e PIB per capita.

Palavras-chave: Desastres. Defesa civil. Gastos públicos. Desenvolvimento.

\section{INTRODUCTION}

Economic damage in disasters that occurred in the 1998-2017 period was estimated at US\$ 2.9 billion, 68\% higher than the losses reported in the 1978-1997 period (WALLEMACQ \& HOUSE, 2018). These disaster impacts have led to serious obstacles to economic growth, which is measured by the percentage change in economic activity measured through the Gross Domestic product (GDP). Some countries experienced annual losses that represented a significant percentage of GDP, such as Haiti (17.5\%), Honduras (7\%), El Salvador (4.2\%) (WALLEMACQ \& HOUSE, 2018).

In addition to the impacts on economic growth - on GDP -, disasters have effects on development policies. The concept of development is broader than that of economic growth because it considers the way in which wealth is socially distributed, how citizenship is exercised, how life and dignity conditions and access to a healthy environment are assured (CARVALHO, 2002). A development indicator is the Human Development Index (HDI), which includes education, health and income. The HDI offers a counterpoint to the Gross Domestic Product (GDP) per capita, which considers only the economic dimension of development (PNUD, 2020).

There is a growing recognition on the part of multilateral organizations that disasters have caused losses not only to economic growth, but also to development. The Human Development Report 2019 points out that developing countries have suffered, on average, a higher HDI reduction percentage than developed countries when facing disasters (UNDP, 2019). The report also points out that developing countries have less resources to prevent and respond to disasters, as well as to implement public policies for mitigation and/or reduction of disaster risks, whether they be of a structural nature - construction and maintenance of infrastructure, urban planning - or non-structural - development of contingency plans, educational actions, evacuation drills etc.

The Global Assessment Report 2015 points out the need to not only recognize that disasters are obstacles to development, but also stresses that it is necessary to understand disasters as poorly resolved development problems (UNISDR, 2015). That is, it is necessary to incorporate disaster risk management as a fundamental component of the development models to be adopted. Disaster risk is a product that results from the combination of hazard (s), vulnerability, capacity and larger-scale risk mitigation policies (WISNER et al., 2012).

Hazards are phenomena that can contribute to triggering probable harm. Vulnerability is conceptualized as the potential to suffer losses and damages in the face of the hazard(s) and to recover after its occurrence. In addition to economic poverty, vulnerability considers other dimensions of deprivation, such as lack of physical capacity, insecurity, social isolation, lack of political power (CHAMBERS, 1989), and has several types, such as institutional vulnerability, which is characterized by obsolescence and rigidity of institutions, prevalence of political decisions on technical-scientific criteria etc. (WILCHES-CHAUX, 1993). 
The capacities against these hazards and the risk mitigation policies - as exemplified previously are important components for reducing impacts, that is, for disaster risk reduction (DRR). With the increasing impacts of disasters, different countries have adopted disaster risk governance arrangements. Governance in the context of risks and disasters means the process of defining competences and coordinating organizations, public and private actors, laws, regulations and standards in order to reduce the risks of disasters and their impacts (TIERNEY, 2012).

One of the important components of governance is the financing policies for Disaster Risk Management (DRM). When examining the DRM financing programs, Kellet and collaborators (2014) identified very heterogeneous approaches and stressed that the problem is not only the lack of financial resources, but the lack of coordination between the different levels of government, mechanisms for funding by municipalities, transparency and accountability.

Scientific analyzes of DRM financing policies are still scarce in the scientific literature, especially in the Latin American context (KELLET et al., 2014). Among Latin American and Caribbean countries, Brazil has a history of recent disasters with significant impacts, such as the disaster related to floods and landslides in November 2008, in Santa Catarina, with losses and damages estimated at R\$ 5.32 billion (BANCO MUNDIAL, 2012a); the June 2010 floods in Pernambuco, with losses and damages of around $\mathrm{R} \$ 3.4$ billion (BANCO MUNDIAL, 2012b); and the catastrophe in the mountainous region of Rio de Janeiro, when more than 900 people died in floods and landslides in January 2011 and about $R \$ 4.78$ billion in losses were accounted for (BANCO MUNDIAL, 2012c).

These disasters catalyzed investments by the Brazilian government. Marchezini et al. (2017) consider that the trend of increasing the percentage of national GDP invested in DRM follows the global logic. In 2006, the percentage of GDP invested was only $0.0009 \%$. In 2009, a year after the disaster in Santa Catarina, the percentage increased to $0.02 \%$ of GDP.

In 2010, the percentage increased to $0.04 \%$ of GDP, the highest level in the period analyzed. With the catastrophe in Rio de Janeiro in 2011, the percentage of GDP invested in DRM increased successively in the following two years (0.015\% of GDP in 2012; $0.023 \%$ of GDP in 2013), decreasing again in 2014 (0.011\% of GDP).

The scope of financial resources in DRM also includes those for disaster response, a topic with few scientific analyzes (KELLET et al., 2014). This article aims to analyze the public policy of financial assistance for disaster response actions in the period 2013 to 2017, when the Civil Defense Payment Card (CPDC) is implemented. CPDC is a way of transferring resources within the scope of the National System for Civil Defense and Protection (SINPDEC).

The organization of SINPDEC is presented briefly in the second section of this article, highlighting the main management instruments related to financial assistance for response actions: i) the Brazilian Disaster Codification; ii) the Disaster Information Form; iii) the declaration of State of Emergency (SE) and the State of Public Calamity (SPC); and, iv) the Civil Defense Payment Card (CPDC). Of these four elements, two will be analyzed: a) the SE and SPC statements; and, b) the financial aid expenses for response actions through the CPDC. After this characterization, the third section describes the method and data used.

Then, in the fourth section, basic statistics and spatial-temporal distributions of disasters and use of CPDC by states and municipalities in the period 2013-2017 are presented. Still in the fourth section, based on a sample of the 30 municipalities that spent more than R\$ 1 million on the CPDC, a correlation analysis is made between the CPDC spending profile of these municipalities and other municipal indicators: the MHDI - as an indicator of development - and GDP per capita - as an indicator of economic growth. These results of the Brazilian case are discussed, in the fifth section, based on scientific studies that have addressed funding and financial assistance policies in disaster response actions in other countries. Finally, in the conclusions and recommendations, suggestions for improving public policy are presented based on the data presented in the analysis. 


\section{THE NATIONAL SYSTEM FOR CIVIL DEFENSE AND PROTECTION}

The National Department for Civil Defense (SEDEC) (CASTRO et al., 2004) considers civil defense activities as a "set of preventive and relief actions designed to avoid or minimize disasters, preserve the morale of the population and restore social normality".

According to this federal management body (BRASIL, 2017), preventive actions refer to measures for planning the occupation of geographical space and the execution of works and services in areas considered at risk. The response actions include rescue activities, restoration of essential services and assistance to those affected, that is, emergency measures aimed at serving the population (BRASIL, 2017).

Finally, recovery and reconstruction actions are defined as the activities developed "after disaster response operations and aimed at recovering the infrastructure and restoring, in its entirety, public services, the economy of the area, social morality and the well-being of the population" (CASTRO et al., 2004).

Civil defense actions are organized in the form of a National System for Civil Defense and Protection (SINPDEC), composed of: consultative body (National Council for Civil Defense and Protection); central body (SEDEC), state bodies and the Federal District, and, sometimes, regional coordinators in those states; municipal civil defense agencies; and, finally, sectoral bodies, from the three spheres of government. It should also be noted that SINPDEC is responsible for implementing the National Policy on Civil Defense and Protection - PNPDEC and that it can mobilize civil society to act in a disaster situation, coordinating logistical support for the development of civil defense and protection actions (BRASIL, 2017).

One of the guiding elements of civil defense activities is the typology of hazards and disasters. With the 2011 catastrophe and the adoption of PNPDEC, SEDEC adopts the Brazilian Classification and Codification of Disasters (COBRADE) which is "corresponding to the classification of disasters in the International Disaster Database (EM-DAT)" (BRASIL, 2017, p.30). COBRADE has two broad categories of hazards: 1) natural; and, 2) technological.

The natural category covers five groups of hazards, some divided into subgroups (BRAZIL, 2017): i) geological (earthquake, volcanic emanation, erosion, mass movement such as landslides); ii) hydrological (river floods, flash floods, surface water floods); iii) meteorological (cyclones, heat waves, etc.); iv) climatological (drought); and, v) biological (epidemics and infestations/pests).

The technological category includes five other groups of hazards: i) disasters related to radioactive substances; ii) disasters related to dangerous products; iii) disasters related to urban fires; iv) disasters related to civil works; and, v) disasters related to the transportation of passengers and non-dangerous cargo (BRASIL, 2017).

Faced with a disaster in the municipality, the civil defense must choose a single type of hazard/disaster at COBRADE and complete the Disaster Information Form (FIDE) to assess the damage in that disaster.

FIDE filling out is guided by manuals (BRASIL, 2017) and must take place online through the Integrated Disaster Information System (S2ID), one of the requirements for the request for recognition of a State of Emergency (SE) or State of Public Calamity (SPC).

\subsection{PROCEDURES FOR DECLARING SE AND SPC}

In Brazil, one of the mechanisms of disaster management is the declaration of SE or SPC. SE is the "recognition (legal) by the public authorities of an abnormal situation, caused by disasters, causing surmountable (bearable) damage by the affected community". The SPC, on the other hand, is the "recognition (legal) by the public authorities of an abnormal situation, provoked by disasters, causing serious damage to the affected community, including the safety or the lives of its members" (BRASIL, 2007, p.8). 
In the legal framework, the term of validity of the SE or SPC decree "varies between 30, 60 and 90 days, which may be extended to 180 days" (BRASIL, 2007, p.24).

The SE or SPC decree process by municipalities, states and the Federal District is governed by procedures and criteria established in Normative Instruction no 02, of December 20, 2016 (BRASIL, 2016). This Normative Instruction establishes some concepts to guide the operationalization of the policy, such as the definitions of damage, loss, disaster, response and resources:

- DAMAGE: result of human, material or environmental losses inflicted on people, communities, institutions, facilities and ecosystems, as a result of a disaster.

- LOSS: extent of loss related to the economic, social and patrimonial value of a given asset, in circumstances of disaster.

- DISASTER: result of adverse events, natural, technological or of anthropic origin, on a vulnerable scenario exposed to the hazard, causing human, material or environmental damages and consequent economic and social damages.

- RESPONSE: emergency measures, carried out during or after the disaster, aimed at the relief and assistance of the affected population and the return of essential services.

- RESOURCES: set of material, human, institutional and financial assets that can be used in case of disaster and are necessary to restore normalcy.

The main criterion for the decree is the intensity of the disaster. The normative instruction establishes that "disasters of level I and II give rise to the decree of SE, while disasters of level III to SPC" (BRASIL, 2016). Table 1 compiles the definitions of these three levels that guide the decree.

Table 1 | Disaster intensity levels, defined by SINPDEC.

\begin{tabular}{|c|c|c|}
\hline Disaster intensity & \multicolumn{1}{c|}{ Definition } \\
\hline LEVEL I & $\begin{array}{r}\text { Level I disasters are those in which there is only considerable human losses and that the situation of } \\
\text { normality can be reestablished with the resources mobilized at the local level or reinforced by the } \\
\text { contribution of state and federal resources. (Art. 2nd § 1st) }\end{array}$ \\
\hline LEVEL II & $\begin{array}{r}\text { Characterized by the occurrence of at least two types of losses, one of them being obligatory human } \\
\text { losses that have an impact on the public economic loss or in the private economic loss that affect the } \\
\text { capacity of the local government to respond and manage the installed crisis. (Art.3rd) }\end{array}$ \\
\hline LEVEL III & $\begin{array}{r}\text { Characterized by the concomitant existence of deaths, isolation of the population, interruption } \\
\text { of essential services, interdiction or destruction of housing units, damage or destruction of public } \\
\text { facilities providing essential services and public infrastructure works (Art.4th) }\end{array}$ \\
\hline
\end{tabular}

Source: Brazil (2016).

Proof of the occurrence of these criteria is requested through forms, among which FIDE stands out, technical documents and audiovisual records that assist in the understanding of the damage (BRASIL, 2017). The set of this documentation is electronically sent via the S2ID. After the occurrence of an event that causes damage within the intensity levels explained in Table 1, it will be up to the municipality, or the State, to send the information by S2ID within the period stipulated by the normative instruction, in general, from 15 to 20 days, a period that varies according to the type of disaster ("sudden, gradual or chronic evolution").

After analyzing the documentation, the federal entity - SEDEC - may or may not recognize the SE and SPC decree request. The homologation of the federal recognition will allow the municipality to request federal resources for the execution of response and recovery actions. The use of these resources for response will take place through the civil defense payment card. 


\subsection{THE CIVIL DEFENSE PAYMENT CARD}

CPDC is a specific means for implementing federal resources for response actions, assistance to those affected and reestablishment of essential services (BRASIL, 2017). It was designed to fulfill two main objectives: i) "accelerate the transfer of resources to municipalities and states (...)"; and, ii) "provide transparency and social control in the use of these resources" (BRASIL, 2017, p.68). CPDC is a form of payment based on legal instruments (BRASIL, 2017) that require, on the part of civil defense agencies, technical, legal and tax knowledge.

In order to use the resources, civil defense agencies need to acquire CPDC from Bank of Brasil (Banco do Brasil) before declaring SE or SPC. Without joining the CPDC, even if the SE or SPC is recognized, the entity will not be able to receive federal funds for response actions, assistance to the victims and reestablishment of essential services (BRASIL, 2017).

An important issue of these disaster management mechanisms refers to definitions of what response, assistance and the restoration of essential services consist of. The definitions are important guidelines for the use of CPDC. Federal decree $n^{\circ}$ 7.257, of August 4, 2010 establishes these definitions:

RESPONSE ACTIONS: they are "immediate actions to respond to disasters with the objective of helping the affected population, including search and rescue, first aid, pre-hospital care and emergency medical and surgical care (...)".

ACTIONS TO ASSIST VICTIMS: "Immediate actions aimed at guaranteeing conditions of safety and citizenship to those affected, including the supply of drinking water, the provision and means of preparing food, the supply of shelter, clothing, cleaning and personal hygiene, the installation of laundries, bathrooms, logistical support for the teams committed to the development of these actions, comprehensive health care, handling the dead (...)"

ACTIONS FOR THE ESTABLISHMENT OF ESSENTIAL SERVICES: "emergency actions aimed at restoring safety and habitability conditions in the area affected by the disaster, including the dismantling of buildings and works of art with compromised structures, the supply and distribution of electricity, drinking water, sewage, urban cleaning, rainwater drainage, public transportation, traffic, communications, drinking water supply and clearing and debris removal (...)".

The request for these resources through CPDC requires technical preparation of civil defense agencies municipal or state - not only to know these definitions, but also to formulate a Detailed Response Plan (PDR) and submit it to SEDEC.

The PDR requires municipalities or states to add information on the number of human losses, the response actions in progress by the municipality, the items that are needed, the quantity requested, the unit value, justifying the need for each of the requested resources, among other information that requires technical capacity to be properly elaborated, while the municipal teams need to respond to the disaster.

Based on this contextualization about SINPDEC with regard to response actions and some of its main management instruments - the decree of SE or SPC and the CPDC -, the next section describes the method used to obtain the spatial-temporal distributions of the SE/SPC and CPDC costs and, based on distributions, analyze these two types of data. 


\section{METHOD}

In this article, the years 2013 to 2017 were considered for analysis, because it is in this period that the two databases are available: i) the SE and SPC statements; and, ii) data from the Civil Defense Payment Card (CPDC).

The data referring to SE and SPC statements were obtained from the S2ID website (https://s2id.mi.gov. $\mathrm{br} /$ paginas/) and contain information such as the name of the municipality, the type of hazard according to COBRADE typology, the date of the SE or SPC decree and the date of publication of the ordinance in the Federal Official Gazette (Table 2). CPDC data were extracted from the Transparency Portal of the Federal Government. Table 2 presents the attributes of the data obtained from the two different portals consulted, as mentioned.

Table 2 | Attributes of the data obtained from the S2ID and the Transparency Portal

\begin{tabular}{|c|c|c|}
\hline \multicolumn{2}{|c|}{ Attributes } \\
\hline Declarations of SE or SPC (S2ID) & \multicolumn{2}{|c|}{ CPDC (Transparency Portal) } \\
\hline FU & Code superior body & Executor expense \\
\hline Geocode & Name superior body & Number agreement \\
\hline Municipality & Code body & Code contracting party \\
\hline Decree & Nome body & Name contracting party* \\
\hline datadec (decree date) & Code managing unit & Transfer \\
\hline Disaster & Name managing unit & Transaction \\
\hline SE or SPC & Year statement & Date transaction \\
\hline Ordinance & Month statement & \\
\hline DOU (Official Gazette of the Union) & CPF holder & \\
\hline NDOU (number of the Official Gazette of the Union) & Holder name & \\
\hline DtDOU (Date of the Official Gazette of the Union) & $\begin{array}{c}\text { CNPJ or CPF of the } \\
\text { beneficiary** }\end{array}$ & \\
\hline Rite & Name of the beneficiary & \\
\hline
\end{tabular}

* It is the beneficiary of CPDC, the municipal or state agency.

** It is the product supplier or service provider who will receive payment.

Source: Elaborated by the authors

In the S2ID data, two types of errors were found and adjusted: one in which the attribute "geocode" did not match the name of the municipality and another in which the name of the municipality was not spelled according to what appears in the IBGE database.

In addition, the disaster typology (disaster attribute) does not specify exactly the event and, in many cases, groups them, in addition to not adopting standardized terminology and referring to the same typology using different expressions. Regarding the Transparency Portal, two limitations are mentioned in the records: i) a large part of the agreement is the State and not the municipalities, thus making the delimitation of the area which has suffered disasters unfeasible; and, ii) the Transparency Portal does not describe the type of disaster or any details about the cause that culminated in the need to use CPCD resources.

After making the necessary adjustments, the data were included in a Geographic Information System environment in order to perform the spatial distribution of data regarding the SE and SPC declarations, considering the following criteria:

1. the number of reporting municipalities per year, which indicates the number of municipalities with disasters recognized by SEDEC; 
2. the number of SE or SPC per year, which indicates the number of disasters recognized by SEDEC;

3. the frequency of declarations by municipality, that is, the frequency of disasters by municipality;

4. the number of SE or SPC by type of event, that is, by type of disaster according to COBRADE typology.

The next step consisted of a selection in the database regarding the use of the CPDC. At this stage, the data were analyzed in order to obtain:

1. the distribution of total expenses with the CPDC per year, which explain the federal financial aid for disaster relief and response actions;

2. The total value over the entire period and also per year of CPDC resources that the States used for response actions in the municipalities

3. the number of municipalities that used CPDC;

4. a ranking of the 30 municipalities with the highest use of CPDC whose data were correlated with other municipal indicators that express their level of development (Municipal Human Development Index-MHDI), obtained in PNUD (2013) and economic (Gross Domestic Product per- capita), obtained from IBGE (2017).

Since the databases for SE and SPC declarations and CPDC spending were not associated, it was not possible to discriminate CPDC spending by the types of disasters contained in the declarations.

\section{RESULTS}

In this section are presented, for the period 2013-2017, some statistics and maps of the spatial-temporal distributions derived from the SE and SPC declarations and CPDC spending databases described in section 3.

\subsection{STATISTICS RELATING TO SE AND SPC DECLARATIONS}

Of the 5570 municipalities in Brazil, 3057 municipalities (54.88\%) declared, at least once, SE or SPC due to disasters in the period 2013-2017 - an average of 1746 municipalities per year (31.34\% of those existing in Brazil).

There were 13894 disasters recognized by SEDEC, an average of 2778 per year. In the period, 51 disasters were considered as SPC, that is, classified as the maximum intensity category - level III.

Dry spells and droughts account for $81.78 \%$ of these records and have been frequent, mainly in the Northeast Region. River floods, flash floods and surface water floods are the second with the highest percentage of records $(9.37 \%)$ and are distributed in the South (58.91\%), North (19.05\%) and Southeast (11.9\%) regions. Table 3 shows a summary of statistics on the SE and SPC declarations in the analyzed period. 
Table 3 | Statistics of spatial-temporal distributions of SE-SPC declarations

\begin{tabular}{|c|c|c|c|c|c|c|}
\hline \multicolumn{4}{|c|}{ № of municipalities that declared SE or SPC at least once } & \multicolumn{3}{|c|}{$3057^{*}$} \\
\hline \multicolumn{2}{|c|}{ № total of declarations } & \multicolumn{2}{|c|}{ NNo of declarations of SE } & \multicolumn{3}{|c|}{ № of declarations of SPC } \\
\hline \multicolumn{2}{|c|}{13894} & \multicolumn{2}{|l|}{13843} & \multicolumn{3}{|c|}{51} \\
\hline \multicolumn{7}{|c|}{ Number of declarations and reporting municipalities per year } \\
\hline Year & \multicolumn{3}{|c|}{ № of declarations } & \multicolumn{3}{|c|}{ № of reporting municipalities } \\
\hline 2013 & \multicolumn{3}{|c|}{3747} & \multicolumn{3}{|c|}{1938} \\
\hline 2014 & \multicolumn{3}{|c|}{2666} & \multicolumn{3}{|c|}{1886} \\
\hline 2015 & \multicolumn{3}{|c|}{2511} & \multicolumn{3}{|c|}{1592} \\
\hline 2016 & \multicolumn{3}{|c|}{2072} & \multicolumn{3}{|c|}{1450} \\
\hline 2017 & \multicolumn{3}{|c|}{2898} & \multicolumn{3}{|c|}{1864} \\
\hline \multicolumn{7}{|c|}{ Percentage distribution of total declarations by region } \\
\hline North (N) & Northeast (NE) & Central-west (CW) & \multicolumn{2}{|c|}{ Southeast (SE) } & \multicolumn{2}{|c|}{ South (S) } \\
\hline $2.41 \%$ & $73.16 \%$ & $1.38 \%$ & \multicolumn{2}{|c|}{$11.35 \%$} & \multicolumn{2}{|c|}{$11.69 \%$} \\
\hline \multicolumn{7}{|c|}{ Percentage distribution of frequency of declarations } \\
\hline \multirow{2}{*}{ Frequency ranges } & Percentage of & & entage of $n$ & cipalities & y region & \\
\hline & $\begin{array}{l}\text { the total of } 3 \text { bs } \\
\text { municipalities }\end{array}$ & $N$ & $N E$ & $C W$ & $S E$ & $S$ \\
\hline 1 to 4 & $58.62 \%$ & $8.15 \%$ & $21.60 \%$ & $7.31 \%$ & $19.03 \%$ & $43.92 \%$ \\
\hline 5 to 7 & $12.82 \%$ & $2.80 \%$ & $71.94 \%$ & $0.00 \%$ & $18.37 \%$ & $6.89 \%$ \\
\hline 8 to 10 & $22.44 \%$ & $0.00 \%$ & $90.23 \%$ & $0.00 \%$ & $9.62 \%$ & $0.15 \%$ \\
\hline 11 to 12 & $6.12 \%$ & $0.00 \%$ & $98.93 \%$ & $0.00 \%$ & $1.07 \%$ & $0.00 \%$ \\
\hline & Percentage dis & ribution of total declo & tions by ty & f hazard & & \\
\hline & & Type of hazard & & & & Percentage \\
\hline Dry spells and d & hts (DSD) & & & & & $81.78 \%$ \\
\hline River floods, flas & ods and surface w & ter floods (RFFFSWF) & & & & $9.37 \%$ \\
\hline Local convective & rms and heavy rain & (LCTHR) & & & & $5.30 \%$ \\
\hline Mass landslides & & & & & & $0.17 \%$ \\
\hline Other** & & & & & & $3.38 \%$ \\
\hline & Percentage distribu & ion of total declaratic & by type of & ard by re & & \\
\hline & & & entage of & arations b & region & \\
\hline & & $N$ & $N E$ & $C W$ & $S E$ & $S$ \\
\hline & & $0.54 \%$ & $88.40 \%$ & $0.10 \%$ & $10.49 \%$ & $0.47 \%$ \\
\hline RFFI & & $19.05 \%$ & $7.14 \%$ & $3.00 \%$ & $11.90 \%$ & $58.91 \%$ \\
\hline & & $0.81 \%$ & $1.49 \%$ & $16.96 \%$ & $16.83 \%$ & $63.91 \%$ \\
\hline & & $4.16 \%$ & $16.67 \%$ & $0.00 \%$ & $41.67 \%$ & $37.50 \%$ \\
\hline OT & & $21.66 \%$ & $2.12 \%$ & $3.61 \%$ & $64.12 \%$ & $8.49 \%$ \\
\hline
\end{tabular}

* corresponding to $54.88 \%$ of the total of 5570 municipalities in Brazil.

** technological, biological disasters, tornadoes, cyclones, hail, fires, erosions, debris flow.

\section{2 - SPATIAL-TEMPORAL DISTRIBUTIONS OF SE AND SPC DECLARATIONS}

In the period covered, Brazil recorded several disasters, such as the river floods of 2012, 2014 and 2015 in Acre (AC); droughts in the Amazon in 2015-2016; river floods, flashfloods and landslides in the Southeast, especially in the states of MG, ES, RJ in 2013; the catastrophe associated with the rupture of the dam in Mariana-MG in 2015; drought in the semiarid region from 2012 to 2017.

Figure 1 shows the spatial-temporal distribution of disaster statements. The Northeast Region accounts for $73.16 \%$ of disasters in the period. Dry spells and droughts account for more than half of the annual 
average, being more than 1500 municipal notifications per year, especially in the Northeast Region and in the North of the State of MG (Southeast Region). In 2013, there were 13 municipalities that declared SE four times, all located in the Northeast Region.
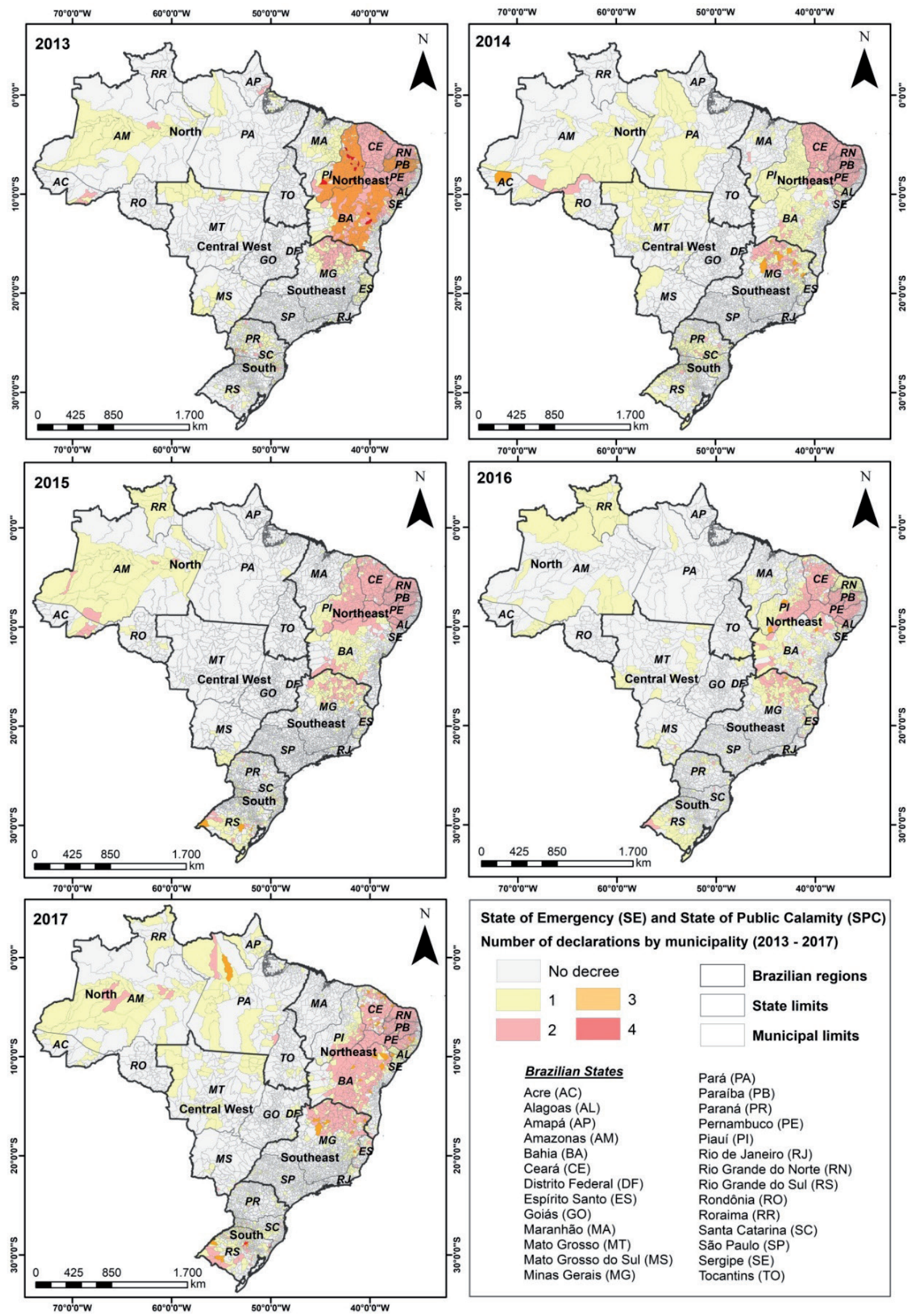

State of Emergency (SE) and State of Public Calamity (SPC) Number of declarations by municipality (2013 - 2017)

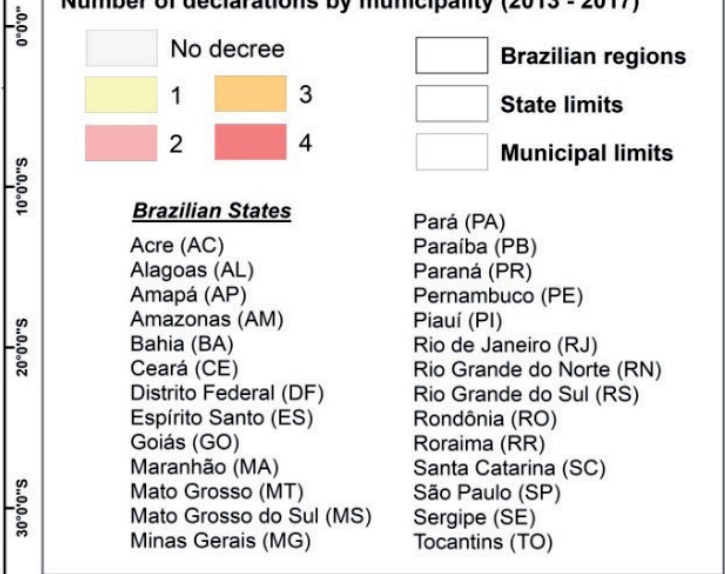

Figure 1 | Spatial-temporal distribution of SE-SPC declarations in Brazil, 2013-2017 period.

Source: Elaborated by the authors, based on data from S2ID. 
Figure 2 presents the map of the spatial distribution of the frequency of declarations for the analyzed period and also a graph indicating the total declarations made by each State in each year. In 185 municipalities in the Northeast Region (which corresponds to $10.31 \%$ of the municipalities in the Region), the frequency of declarations reached the range between 11 and 12 records, an average of more than two declarations per year. The highest occurrence was in the State of Paraíba (PB) with 170 municipalities, with emphasis on São José de Piranhas, with 12 declarations.

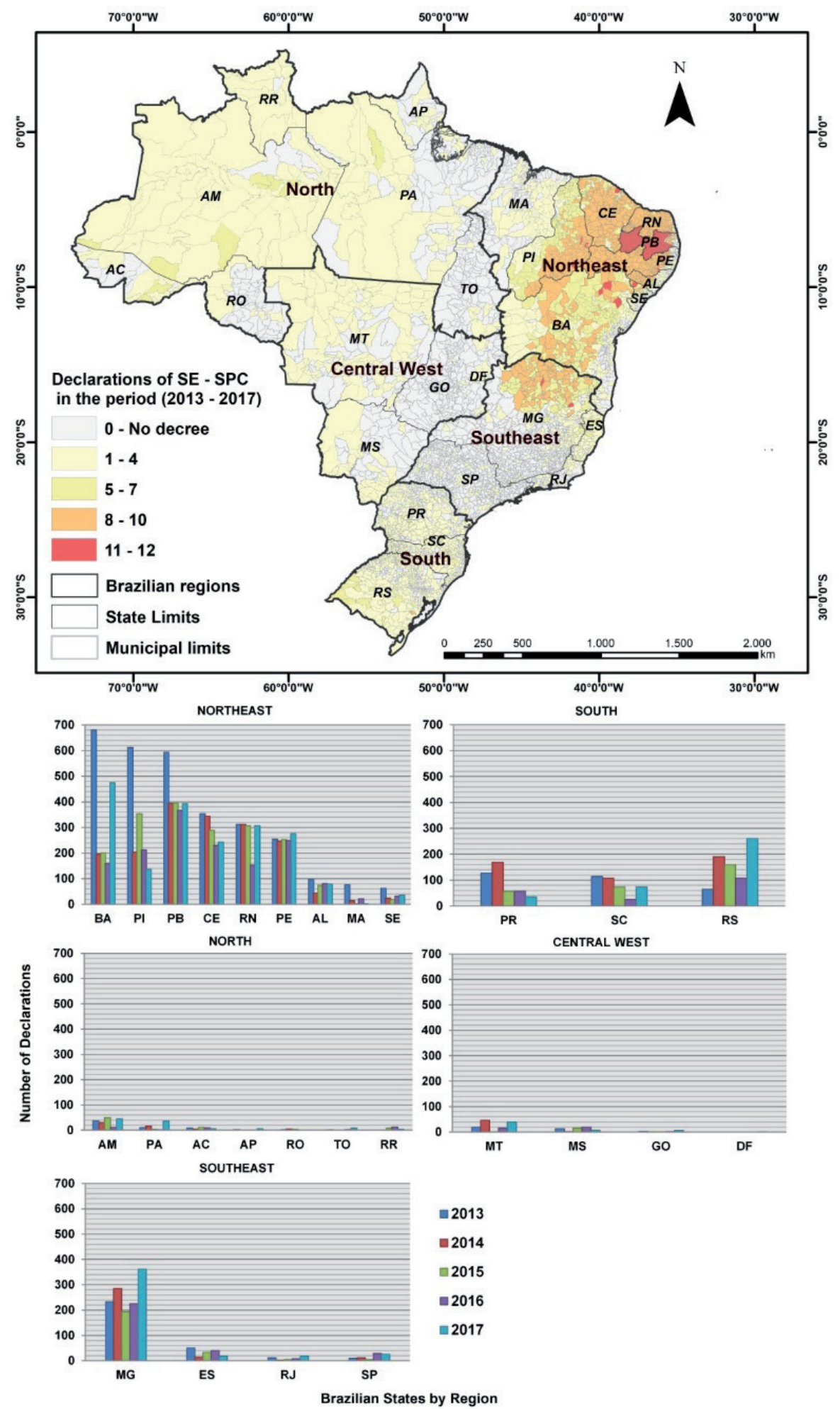

Figure 2 | Spatial-temporal distribution of the frequency of declarations of SE-SPC in Brazil, period 2013-2017, and bar chart with the total of declarations of States in each year. 
Most municipalities that declared SE-SPC due to river floods, flash floods and/or surface water floods did so more than once a year, especially in the South and North Regions. There is also the scenario in which municipalities experienced multiple hazards in the same year or over the period, such as the municipality of Rio Branco - AC, which in 2013 declared SE for both drought and river flood. Or the municipalities of Brasiléia and Epitaciolândia, both in the AC, which declared SE due to drought and also due to viral infectious diseases. Figure 3 illustrates the temporal distribution of SE - SPC by hazard type.

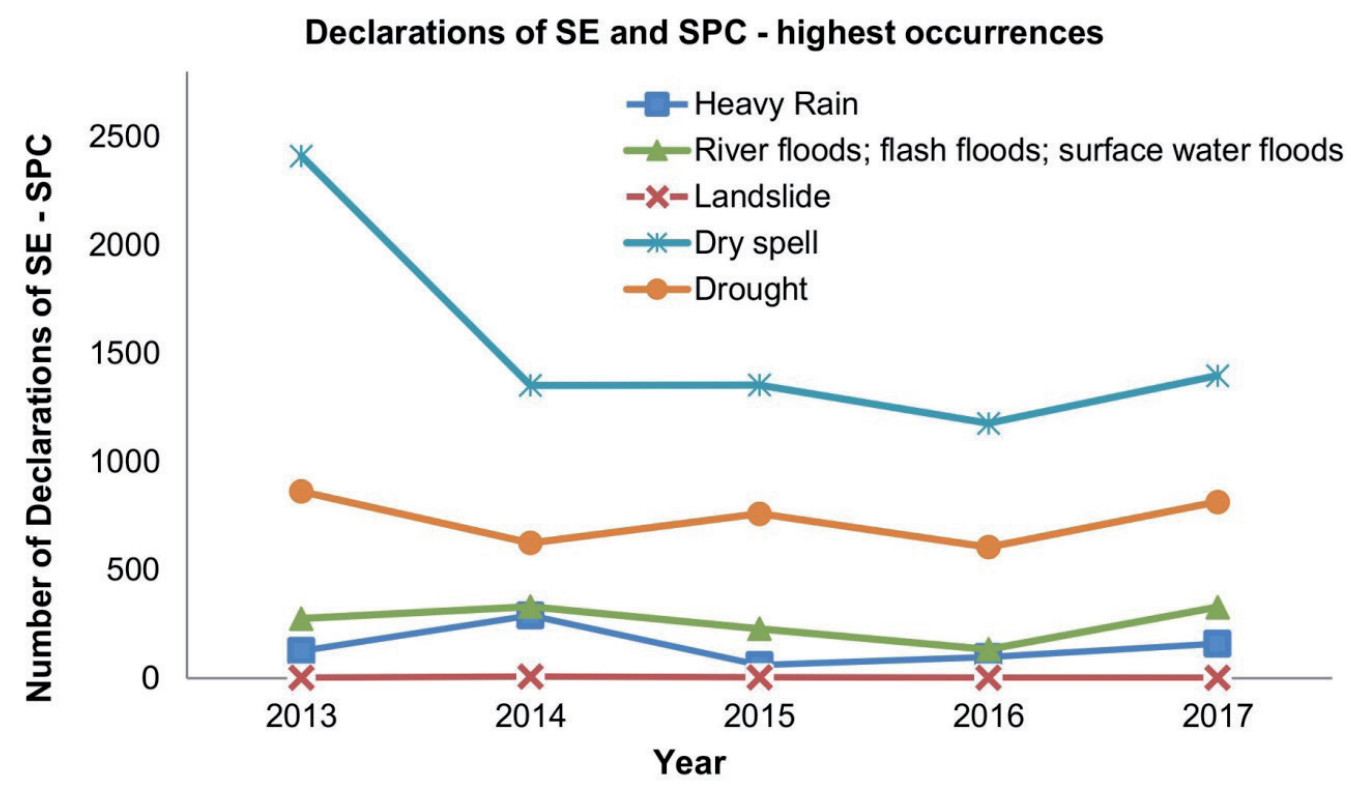

Figure 3 | Temporal distribution of SE-SPC declarations by type of threat in the period 2013-2017.

Source: Elaborated by the authors, based on data from S2ID.

One aspect that draws attention is the low amount of SE-SPC registration due to landslides, forest fires, technological and biological disasters. Technological disasters totaled 15 declarations, with the highest occurrence in 2015, associated with the rupture of dams in the State of MG. Biological disasters were concentrated in 2017 with 68 declarations, 62 in municipalities in MG, due to viral infectious diseases.

\subsection{STATISTICS RELATING TO CPDC EXPENSES}

States and municipalities that enact SE and SPC can use the CPDC. In cases of disasters that affect more than one municipality - such as those related to dry spells and droughts -, state civil defenses themselves can make use of the CPDC in favor of the municipalities that have been approved by SE and SPC. However, through the data available on the Transparency Portal, it is not possible to discriminate in favor of which municipalities these spending were made.

Of the total expenses with CPDC in the period - approximately $\mathrm{R} \$ 807.7$ million - 76.45\% (R\$ 617.9 million) were used with the intermediation of 21 Brazilian states and $23.55 \%$ ( $R \$ 189.7$ million) directly by 564 municipalities (Table 4). Among the 21 States, the first nine positions were occupied by those in the Northeast region, with emphasis on CE, PE, PI and AL, which accounted for just over half of the resources used by the States.

Table 4 shows the expenses with the CPDC made with the intermediation of the States and the municipalities that are part of it, together with the number of declarations of SE and SPC in the analyzed period. It is ranked from highest to lowest total expenses on CPDC in order to facilitate the perception that the magnitude of these expenses is not directly related to the number of SE and SPC declarations 
made by the State and its municipalities. The State of Paraíba (PB), for example, recorded the largest number of SE and SPC declarations in the period (2142) and had total spending with the CPDC that were lower than the State of Ceará (CE). CE registered almost the same number of declarations as PI and its total spending on CPDC was 2.36 times higher.

Table 4 | CPDC expenses and total declarations between 2013 and 2017

\begin{tabular}{|c|c|c|c|c|}
\hline$F U$ & $\begin{array}{c}\text { CPDC Expenses } \\
\text { by State }\end{array}$ & $\begin{array}{l}\text { CPDC Expenses } \\
\text { by Municipalities }\end{array}$ & Total CPDC Expenses & $\begin{array}{c}\text { Number of declarations } \\
\text { SE }+S P C\end{array}$ \\
\hline CE & $148.552 .394,50$ & $481.772,88$ & $149.034 .167,38$ & 1461 \\
\hline PB & $49.917 .265,79$ & $54.198 .609,20$ & $104.115 .874,99$ & 2142 \\
\hline PE & $78.943 .909,35$ & $2.091 .464,87$ & $81.035 .374,22$ & 1279 \\
\hline $\mathrm{PI}$ & $63.033 .887,45$ & $44.595,44$ & $63.078 .482,89$ & 1518 \\
\hline$A L$ & $57.074 .976,28$ & $1.285 .363,18$ & $58.360 .339,46$ & 374 \\
\hline $\mathrm{RN}$ & 48.963.360,96 & $8.716 .256,73$ & $57.679 .617,69$ & 1389 \\
\hline BA & $25.303 .051,71$ & $17.385 .328,13$ & $42.688 .379,84$ & 1711 \\
\hline MG & $21.949 .506,59$ & $19.289 .286,60$ & $41.238 .793,19$ & 1299 \\
\hline AM & $9.751 .670,98$ & 22.943 .570 .20 & $32.695 .241,18$ & 174 \\
\hline MA & $30.781 .129,27$ & 0,00 & $30.781 .129,27$ & 117 \\
\hline$A C$ & $14.731 .789,83$ & $9.353 .631,03$ & $24.085 .420,86$ & 40 \\
\hline RJ & 7.656.660,01 & $15.345 .344,73$ & $23.002 .004,74$ & 44 \\
\hline RS & $13.835 .699,28$ & $6.338 .159,53$ & $20.173 .858,81$ & 783 \\
\hline SE & $19.606 .816,26$ & 0,00 & $19.606 .816,26$ & 172 \\
\hline SC & $5.231 .898,86$ & $12.830 .828,75$ & $18.062 .727,61$ & 395 \\
\hline RO & $13.390 .024,26$ & 0,00 & $13.390 .024,26$ & 13 \\
\hline PR & $6.616 .198,20$ & $4.303 .357,67$ & $10.919 .555,87$ & 446 \\
\hline SP & 0,00 & $5.880 .513,93$ & $5.880 .513,93$ & 79 \\
\hline PA & $860.642,00$ & $2.735 .692,49$ & $3.596 .334,49$ & 67 \\
\hline $\mathrm{AP}$ & $237.116,97$ & $2.956 .682,00$ & $3.193 .798,97$ & 8 \\
\hline GO & 0,00 & $1.881 .862,47$ & $1.881 .862,47$ & 13 \\
\hline MT & $1.168 .500,00$ & $97.575,80$ & $1.266 .075,80$ & 121 \\
\hline ES & 0,00 & $960.806,00$ & $960.806,00$ & 155 \\
\hline MS & 0,00 & $627.324,63$ & $627.324,63$ & 57 \\
\hline RR & $357.886,00$ & 0,00 & $357.886,00$ & 25 \\
\hline DF & 0,00 & 0,00 & 0,00 & 1 \\
\hline TO & 0,00 & 0,00 & 0,00 & 11 \\
\hline Total & $617.964 .384,55$ & $189.748 .026,26$ & $807.712 .410,81$ & 13894 \\
\hline
\end{tabular}

Source: Elaborated by the authors, based on data from the Transparency Portal and S2ID.

Average expenses on the CPDC per year was approximately R\$ 161.5 million, with an emphasis on 2014, with R\$ 270 million.

It is possible to identify that in the Northeast Region, States tend to be intermediaries in the use of CPDC resources to be applied in the municipalities in SE and SPC - with the exception of PB, where the use of CPDC resources directly by the municipalities and with the intermediation of the State were proportional in terms of the amount used over the period. In the South and Southeast Regions - with the exception of the States of MG and RS -, an opposite scenario is identified, with municipalities directly accessing financial resources via CPDC. 


\subsection{EXPENSES ON CPDC BY MUNICIPALITY}

Of the 3057 municipalities that enacted SE or SPC, $18.45 \%$ of them (564) made use of CPDC resources on their own.

Of these 564 municipalities, 54.61\% (308) are concentrated in the Northeast Region, mainly in PB (184 municipalities) and BA (118 municipalities). The South Region is the second in number of municipalities (133) using the CPDC, 70 of which (61.95\%) are from SC. The Southeast Region has 60 municipalities using CPDC, the majority (70\%) in MG. In the North Region, AM registered 36 of the 59 municipalities. Figure 4 shows the spatial-temporal distribution of spending with CPDC in the period, by municipal civil defenses.
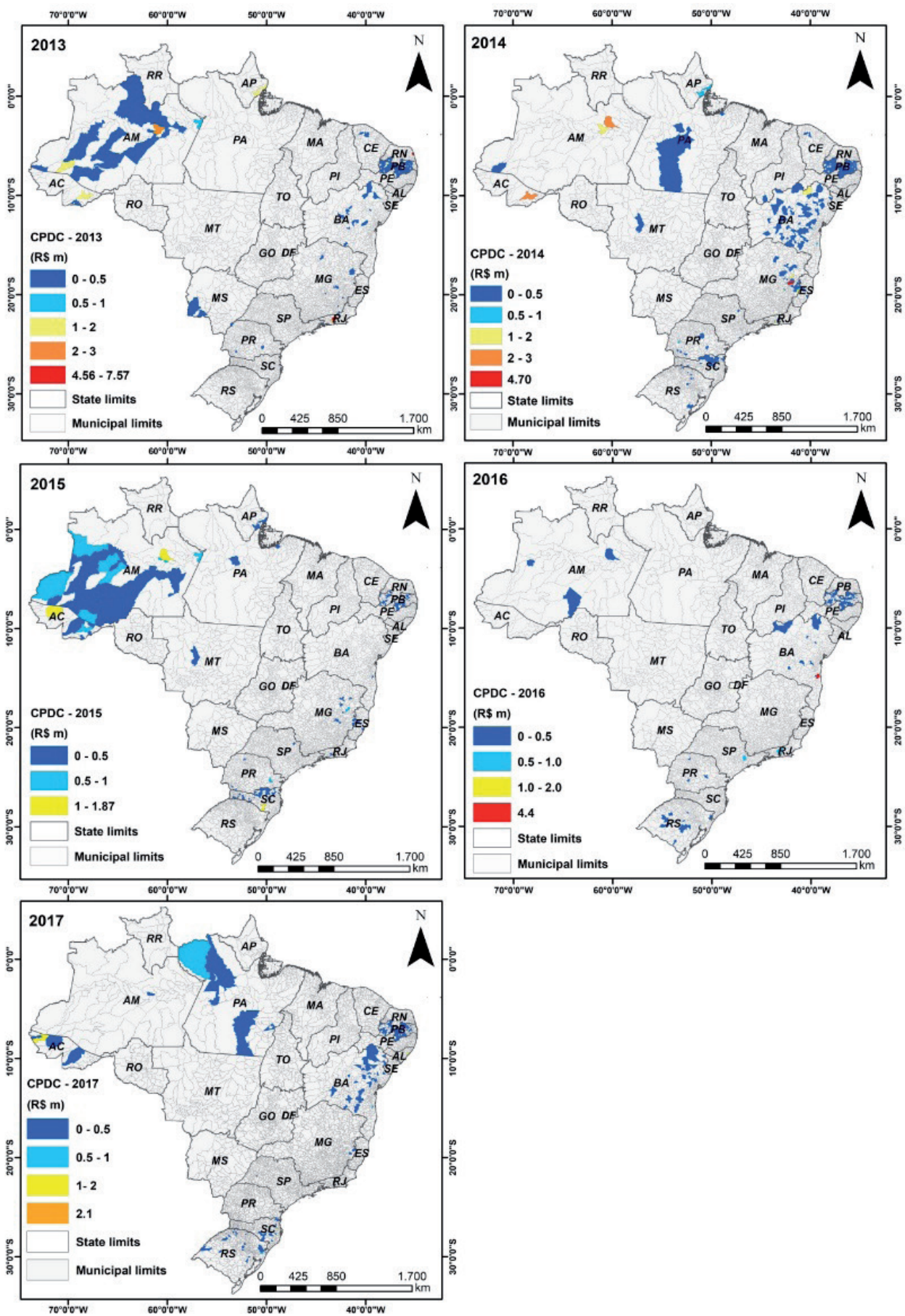

Figure 4 | Distribution of expenses with CPDC in the period 2013 - 2017, by the municipalities. Source: Elaborated by the authors, based on data from the Transparency Portal. 
Of the R\$189.7 million used by 564 municipalities, $41 \%$ (R\$ 77.7 million) were spent by 30 of them. More than half of these municipalities (19) have a high MHDI (above 0.700) (Figure 5). Of this sample, only one municipality had low development (MHDI less than 0.550), that is, a large part of the CPDC's resources has not been used by municipalities with lower MHDI values. All municipalities that had expenses with CPDC greater than R\$ 4 million in the 2013-2017 period had an MHDI greater than 0.700 (Figure 5).

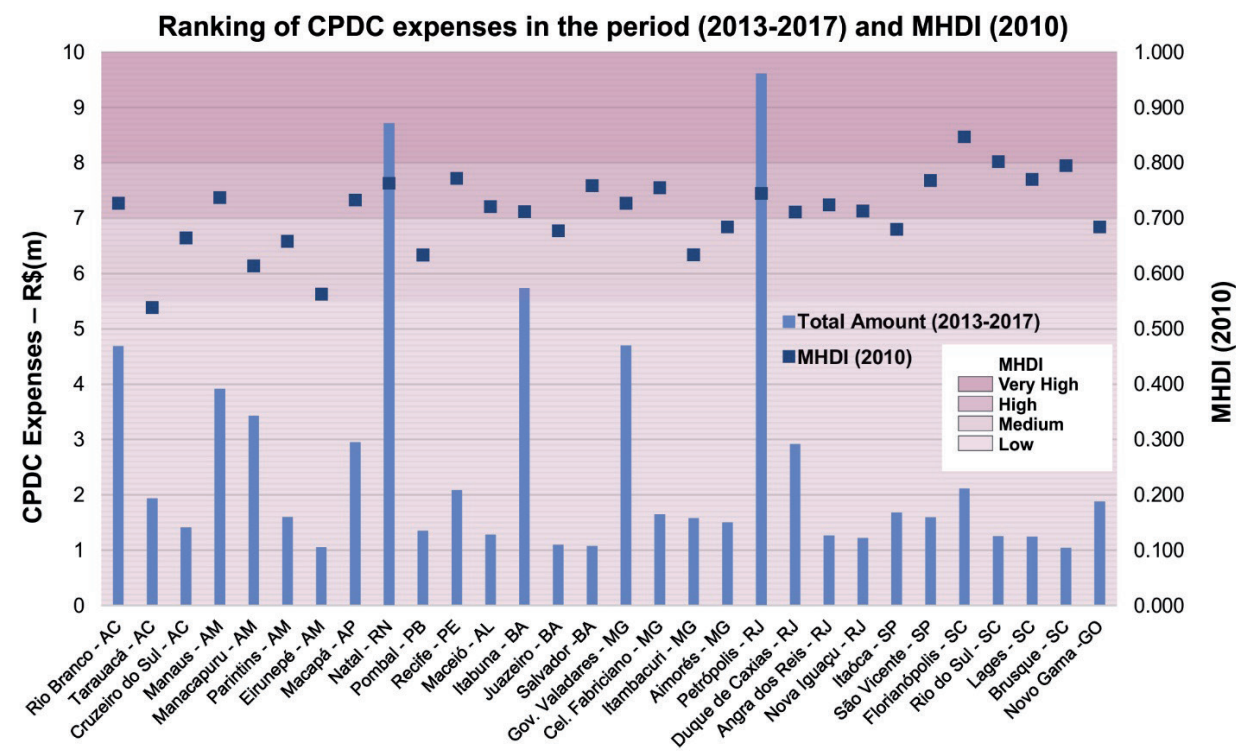

Figure 5 | CPDC values $\mathrm{R} \$(\mathrm{~m})$ and MHDI of the 30 municipalities with the highest expenses in the period.

Source: Elaborated by the authors, based on data from the Transparency Portal and PNUD (2013).

Sometimes municipalities have similar values for MHDI, but are unequal in relation to GDP per capita - an indicator of economic growth. The municipalities of Macapá - AP and Duque de Caxias - RJ have similar MHDI and expenses on CPDC was also similar, but Duque de Caxias-RJ has GDP per capita about twice as high as the GDP per capita of Macapá-AP.

It is important to highlight that among the 30 municipalities in this sample, the municipalities in the states of SC and RJ have GDP per capita higher than the national average, while a large part of the municipalities in the North and Northeast regions of the country are located below it (Figure 6).

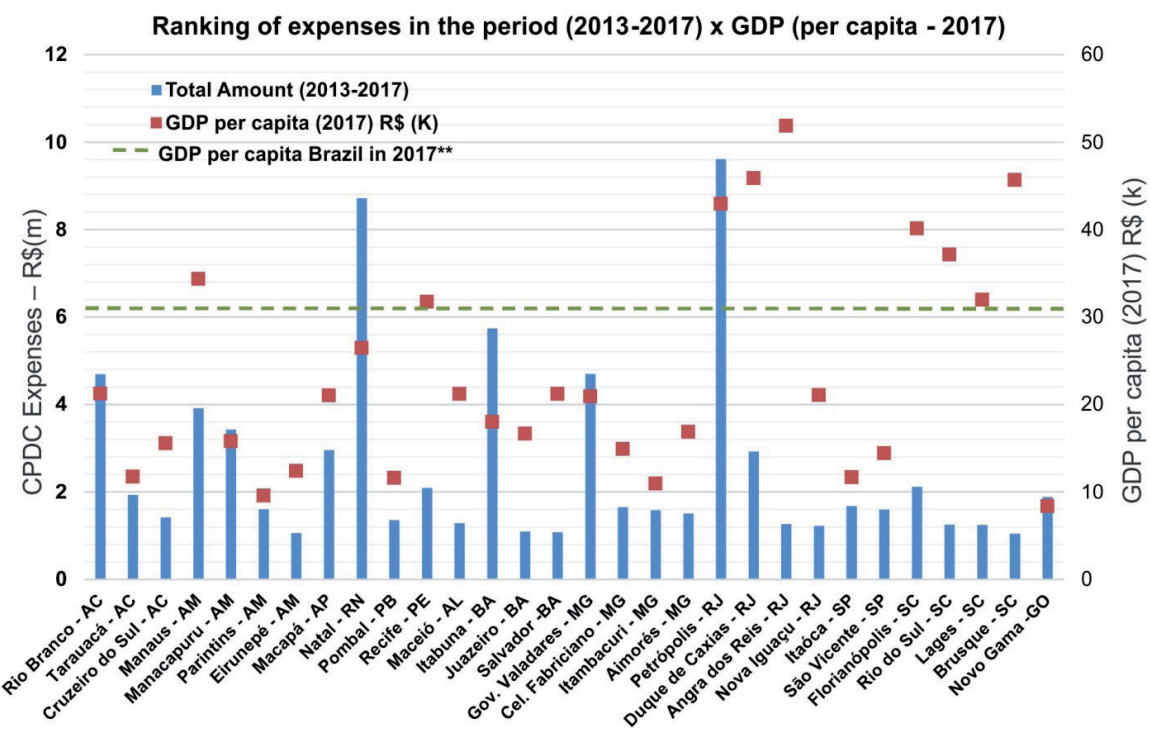

** GDP per capita in 2017: $\mathrm{R} \$ 31.833,50$.

Figure 6 | Values of CPDC R\$ $(m)$ and per capita income of the 30 municipalities with the highest expenses in the period. Source: Prepared by the authors, based on data from the Transparency Portal and the IBGE (2017) 


\section{DISCUSSION}

In the context of institutional vulnerability to disasters, Valencio (2014) proposed to analyze the decrees of SE and SPC as expressions of a chronic crisis in Brazil. When analyzing 19,441 SE and SPC decrees in the period 2004-2013, the author considers that the country is experiencing a kind of disaster pandemic (VALENCIO, 2014), with an annual average of $25 \%$ of municipalities in SE or SPC. When analyzing the 2013-2017 period, we found an increase in this average: almost 32\% of Brazilian municipalities in SE or SPC per year.

In addition to analyzing the spatial-temporal distribution of the SE and SPC declarations (Figure 1), it is also important to identify the consequences that federal recognition implies, such as, for example, requesting access to financial aid for disaster response actions.

When analyzing the spatial-temporal distribution of spending with CPDC by the States and municipalities, in the period 2013-2017, it was possible to identify that in most of the States of the Northeast Region and in the States of MG and RS, the state entity is usually an intermediary in the use of CPDC (Table 4). Is this intermediation by the State entity justified by the disaster affecting more than one municipality and/or the affected municipality not having a municipal civil defense agency?

Future studies need to analyze these dimensions of governance and management within the scope of SINPDEC. In this regard, it is "relevant to emphasize the fact that the duty imposed on the Federal Government to transfer amounts in the event of disasters covers, even as beneficiaries, municipalities that have not fulfilled their respective legal duties to map risk areas, considering such studies in its master plans (...) and preventive actions (CARVALHO, 2020, p.151). It would also be relevant to consider whether municipalities have civil defense with sufficient staff and budget to carry out these actions in the context of disaster prevention, response and recovery.

Furthermore, it is important to analyze whether indicators could be used to prioritize CPDC resources for those municipalities with lower MHDI and per capita income, understanding these two indicators among the set of factors that may represent human development and economic wealth present in the municipalities. In our analysis for the 30 municipalities that most used CPDC in the period, we identified that a large part of them (19) have high MHDI - mainly those located in the South Region of the country. Although the MHDI can be used as one of the parameters for prioritizing CPDC resources, it is important to consider the limitations of the MHDI and other indicators.

Vieira and collaborators (2020), for example, identified an improvement in the MHDI values between 2000 and 2010 for municipalities in the Brazilian semiarid region. However, when analyzing the components that contributed to this change, they identified that health and education indicators generally improved over the years, while socioeconomic indicators remain low in some sets of municipalities, explaining intra-regional inequalities. In other words, in relation to droughts in the Brazilian semiarid region, it would be important to guide public policies not by the climate variable itself, but by the conditions of environmental susceptibility and social, economic and institutional vulnerabilities present in the municipalities (VIEIRA et al., 2020).

CPDC is considered a form of access to a complementary resource (BRASIL, 2017). Should the proportions of complementarity of the resource be the same, regardless of the conditions of development (MHDI) and economic wealth (GDP per capita) of the municipalities? Has the assessment for the release of CPDC resources been guided by the amount of damage and losses reported by the municipalities when they register disasters or by the financial and management capacity they have to provide relief, assistance and restoration services? The results of this article do not allow answering these questions, but the exploratory analysis on a topic that has been little studied in the country - public financial aid policy in response to disasters - has given rise to some of these questions that may have implications on the forms of governance and disaster risk management. 
The exploratory analysis of this public policy allows other questions. In disasters with high visibility in the media, it is common for campaigns to collect donations and cash donations, as occurred in the disaster in the Vale do Itajaí/SC in 2008, when approximately R\$ 35 million were donated in favor of homeless. In Ilhota/SC, people questioned how the financial resources donated to them were being used by public agencies, given that the survivors had not been consulted about how the money donations, deposited in the state entity's bank account, should be used (MARCHEZINI, 2014).

From this example, one could ask: what criteria to adopt when the complementary use of CPDC resources is granted by SEDEC and, in the course of the emergency response, other sources of resources - such as cash donations - are directed to the same States and municipalities?

Spending transparency in response to disasters has been identified as one of the main strengths of CPDC (BRASIL, 2017). Transparency, accountability, lack of coordination between levels of government and local capacity for investment are among the main challenges identified by studies that analyzed funding policies for DRM (KELLET et al., 2014).

Kellet and collaborators (2014) emphasized that the biggest problem is not always the lack of financial resources. To this element of institutional vulnerability we can add another: i) the high concentration of resources at the national level; ii) the lack of allocation of funds to the local level; iii) local capacity to implement DRM actions; iv) coordination mechanisms between levels of government; v) clarity in the legislation; vi) clarity in the roles and responsibilities of each of the government agencies; vii) knowledge of administrative procedures in order to access financing and financial assistance programs; and, viii) availability of data about the funds allocated to which DRM activities.

In the face of these challenges, Kellet and collaborators (2014) recommend improving clarity and sometimes simplifying legislation, as well as focusing on decentralizing resources to promote DRM at the local level. In Brazil, the public financial assistance policy for disaster response actions, via the CPDC, has procedures that require technical and legal capacity on the part of municipal civil defenses.

This is supplemented by the budgetary and financial reality of civil protection and defense in Brazilian municipalities, which, as acknowledged by SEDEC itself (BRASIL, 2017, p.37), in most cases "does not have its own resources (budget line), especially municipalities with a small number of inhabitants and those that do not register a significant frequency of disasters. There are also those who have minimal resources and are unable to execute them".

In view of this reality, it may be important to use CPDC resources to reduce, even if occasionally, the institutional vulnerabilities of these municipalities, especially those with lower MHDI and GDP per capita. Future studies can analyze these dimensions, identifying how municipal civil defense agencies finance their activities, and what effects the lack of financing and institutional capacity can generate on DRM activities.

\section{CONCLUSIONS AND RECOMMENDATIONS}

The analysis of the spatial-temporal distributions of the SE and SPC and of the expenses with the CPDC in the 2013-2017 period allows to identify some conclusions that may be important for the planning of public financial aid policies for disaster response actions.

First, the SE declaration is being treated as something ordinary. More than half of the Brazilian municipalities declared SE in a period of five years. The frequency of declarations is another aspect that draws attention. In 187 Brazilian municipalities, the government deals with SE almost 200 days a year.

Most of the SE declarations are related to dry spells and droughts, especially in the Northeast Region. Other hazards, such as geological and biological hazards, have few records in the S2ID database. 
The declaration of SE or SPC is a step to claim financial aid for response actions, via CPDC. States used most of the CPDC's resources (76.45\%). Four states in the Northeast Region, which have frequent SE records due to dry spells and droughts, account for just over half of all spending. Although SE declarations have the municipality as the disaster site, many seem to depend on the State as an intermediate federative entity for the use of CPDC resources, mainly in the Northeast Region - with the exception of the States of $\mathrm{PB}$ and $\mathrm{BA}-$ and in the States of MG and RS.

Of the set of 564 municipalities that used CPDC, $54.61 \%$ are concentrated in the Northeast (mainly in PB and BA), South (23.58\%), Southeast (10.64\%), North (10.46\%) and, finally, the Central-West $(0.71 \%)$. Of the R\$ 189.7 million directly used by the municipalities, $41 \%$ of the total ( $R \$ 77.7$ million) went to 30 municipalities.

It is interesting to highlight that all the municipalities that had spending with CPDC higher than R\$ 4 million in the period 2013-2017 had High MHDI (higher than 0.700) - especially in the South and Southeast regions of the country. In other words, municipalities with higher HDI and higher GDP per capita - indicators that, in theory, represent better conditions for development - also have more extraordinary resources from the federal government through CPDC, considered a type of complementary aid. Future analyzes will be able to verify if this trend of reproduction of inequality in assistance in disasters is replicated. To what extent have municipalities with lower MHDI values been affected by disasters and have not had access to CPDC resources?

As a way of improving the transparency of the CPDC and making it more appropriate for DRM analyzes, it is recommended that the beneficiary municipalities be detailed when resources are requested by the States, and also that the typology of hazards and disasters be informed on the Transparency Portal. Another important aspect may be to establish criteria for prioritizing CPDC resources based on the history of municipalities in disaster risk reduction.

\section{ACKNOWLEDGMENTS}

VM thanks the São Paulo Research Foundation-Fapesp (Grant number 2018/06093-4). AMF thanks CAPES for the PhD scholarship. DAM thanks CNPq for the EXP-A scholarship.

\section{REFERENCES}

BANCO MUNDIAL. Avaliação de Perdas e Danos: inundações bruscas em Santa Catarina - novembro de 2008. Brasília: Banco Mundial, 2012a.

BANCO MUNDIAL. Avaliação de Perdas e Danos: inundações bruscas em Pernambuco - junho de 2010. Brasília: Banco Mundial, 2012b.

BANCO MUNDIAL. Avaliação de Perdas e Danos: inundações e deslizamentos na Região Serrana do Rio de Janeiro - janeiro de 2011. Brasília: Banco Mundial, 2012c.

BRASIL. Instrução Normativa no 02, de 20 de dezembro de 2016. 2016. Disponível em: <https://www.mdr.gov.br/ images/stories/ArquivosDefesaCivil/ArquivosPDF/legislacao/Anexo-VI---Conceitos.pdf>. Acesso em: 17 jan. 2019.

BRASIL. Ministério da Integração Nacional. Módulo de formação: resposta, gestão de desastres, decretação e reconhecimento federal e gestão de recursos federais em proteção e defesa civil para resposta. Apostila do instrutor. Brasília-DF, 2017. Disponível em: <https://www.mdr.gov.br/images/stories/ArquivosDefesaCivil/ ArquivosPDF/publicacoes/II---Resposta---Livro-Base.pdf>. Acesso em: 17 jan. 2019.

BRASIL. Política Nacional de Defesa Civil. Brasília: Sedec, 2007.

CARVALHO, D. W. Desastres ambientais e sua regulação jurídica: deveres de prevenção, resposta e compensação ambiental. 2. ed. São Paulo: Thomson Reuters, 2020. 
CARVALHO, J. M. Cidadania no Brasil: o longo caminho. Rio de Janeiro: Civilização Brasileira, 2002.

CASTRO, A. L. C. Glossário de Defesa Civil: estudos de riscos e medicina de desastres. 5. ed. Brasília: Sedec, 2004.

CHAMBERS, R. Vulnerability, coping and policy. IDS bulletin, v. 20, n. 2, p. 1-7, 1989.

INSTITUTO BRASILEIRO DE GEOGRAFIA E ESTATÍSTICA. PIB per capita [2017]. IBGE Cidades. 2017. Disponível em: $<$ https://cidades.ibge.gov.br/>. Acesso em: 17 jan. 2019.

KELLETT, J.; CARAVANI, A.; PICHON, F. Financing Disaster Risk Reduction: towards a coherent and comprehensive approach. 2014. Disponível em: <https://www.odi.org/sites/odi.org.uk/files/odi-assets/publications-opinionfiles/9027.pdf>. Acesso em: 07 jul. 2019.

MARCHEZINI, V. Campos de desabrigados: a continuidade do desastre. São Carlos: RiMa, 2014.

MARCHEZINI, V.; SARTORI, J.; GONÇALVES, J. C. Desenvolvimento, Desastres e Reconstrução: o caso de São Luiz do Paraitinga/SP, Brasil. Revista Brasileira de Gestão e Desenvolvimento Regional, v. 13, p. 202-226, 2017.

PROGRAMA DAS NAÇÕES UNIDAS PARA O DESENVOLVIMENTO. Atlas do Desenvolvimento Humano no Brasil 2013. Disponível em: <https://www.br.undp.org/content/brazil/pt/home/idh0/rankings/idhm-municipios-2010. html>. Acesso em: 15 jan. 2019.

PROGRAMA DAS NAÇÕES UNIDAS PARA O DESENVOLVIMENTO. O que é o IDH. Brasília: Pnud, 2020. Disponível em: <https://www.br.undp.org/content/brazil/pt/home/idh0/conceitos/o-que-e-o-idh.html>. Acesso em: 10 jul. 2020.

TIERNEY, K. Disaster governance: social, political, and economic dimensions. Annual Review of Environment and Resources, v. 37, p. 341-363. 2012.

UNITED NATIONS DEVELOPMENT PROGRAM. Human Development Report 2019. Beyond income, beyond averages, beyond today: inequalities in human development in the 21st century. New York: UNDP, 2019. Disponível em: <http://hdr.undp.org/sites/default/files/hdr2019.pdf>. Acesso em: 05 jul. 2020.

UNITED NATIONS INTERNATIONAL STRATEGY FOR DISASTER REDUCTION. Global Assessment Report on Disaster Risk Reduction: making development sustainable. The Future of Disaster Risk Reduction, UN, New York, 2015.

VALENCIO, N. F. L. S. Desastres no Brasil: a face hídrica do antidesenvolvimento. In: VALENCIO, N. F. L. S.; SIENA, M. Sociologia dos Desastres: construção, interfaces e perspectivas. Volume IV. São Carlos: Rima Editora, 2014. p. 109-148.

VIEIRA, R. M. S. P. et al. Characterizing spatio-temporal patterns of social vulnerability to droughts, degradation and desertification in the Brazilian northeast. Environmental and Sustainability Indicators, 2020.

WALleMACQ, P.; HOUSE, R. Economic Losses, Poverty \& Disasters. 2018. Disponível em: <https://www. preventionweb.net/files/61119_credeconomiclosses.pdf>. Acesso em: 1 ago. 2019.

WILCHES-CHAUX, G. La vulnerabilidad global. In: MASKREY, A. (Org.). Los desastres no son naturales, 1993, p. 11-41. LA RED: Panamá.

WISNER, B.; GAILLARD, J. C.; KELMAN, I. Framing disaster: theories and stories seeking to understand hazards, vulnerability and risk. In: London: Routledge, 2012. The Routledge handbook of hazards and disaster risk reduction. p.18-34. 